\title{
Influence of Layered Structure of Composite Timber Floor Boards on Their Hardness
}

\section{Utjecaj strukture slojeva na tvrdoću višeslojnih podnih obloga}

\author{
Original scientific paper • Izvorni znanstveni rad \\ Received-prispjelo: 12. 12. 2018. \\ Accepted-prihvaćeno: 20. 11. 2019. \\ UDK: $630 * 812.731 ; 630 * 832.284 ; 630 * 833.18$ \\ https://doi.org/10.5552/drvind.2019.1856
}

\begin{abstract}
The possibility of using composite elements of flooring pine veneers with knotholes for the production of supporting layers has been determined. This assessment was made on the basis of the Brinell hardness measurement of the face layer of five-layer composites with empty spots in their structure imitating knotholes of various diameters $(10,20$ and $50 \mathrm{~mm}$ ). The dependencies obtained from empirical determinations were supported by numerical analysis. It was found that it is possible to use veneers with defects (empty spots) with a diameter of up to $20 \mathrm{~mm}$ to produce composites of three and more layers of wood (counting from the face layer). The anatomical section of the exposed wood on the face (radial cross-section, tangential section) of the layered composite does not affect the obtained hardness values.
\end{abstract}

Keywords: veneer, composite, flooring material, knotholes, hardness

SAŽETAK • Ispitivanjem je potvrđena mogućnost uporabe furnira od borova drva s rupama od kvrga kao srednjeg sloja u proizvodnji višeslojnih podnih obloga. Ta je procjena napravljena na temelju mjerenja tvrdoće prema Brinellu gaznog sloja peteroslojne podne obloge s rupama različitih promjera (10, 20 i 50 mm) unutar strukture obloge koje simuliraju rupe od kvrga. Ovisnosti dobivene iz empirijskih rezultata potkrijepljene su računskom analizom. Utvrđeno je da je za proizvodnju podnih obloga od tri i više slojeva (brojeći od gaznog sloja) moguće upotrijebiti furnire s greškama (s neispunjenim rupama) promjera do $20 \mathrm{~mm}$. Anatomski presjek izloženog drva na licu višeslojne podne obloge (radijalni i tangentni presjek) ne utječe na vrijednosti tvrdoće.

Ključne riječi: furnir, višeslojna podna obloga, rupe od kvrga, tvrdoća

\section{INTRODUCTION \\ 1. UVOD}

According to the European Federation of the Parquet Industry (FEP), 80.4 million $\mathrm{m}^{2}$ of parquets were produced in Europe in 2016. 80 \% of parquet production included multi-layered materials (excluding laminate floor panels) (FEP, 2018a). Poland maintains top position among producers $(20.08 \%)$, followed by
Sweden (16.99\%), Austria (14.02\%), and Germany (11.97\%). It should be noted that, according to FEP, wood flooring element can only be called "parquet" if its top layer is made of a solid wood with a minimum thickness of $2.5 \mathrm{~mm}$ (FEP, 2018b). Multi-layered structure increases the shape stability of flooring products and reduces the dimensional changes in relation to solid wood elements by up to $75 \%$ (KEN'S YARD,

\footnotetext{
Authors are researchers at Warsaw University of Life Sciences - SGGW, Faculty of Wood Technology, Warsaw, Poland.

${ }^{1}$ Autori su istraživači Sveučilišta prirodnih znanosti u Varšavi, Drvnotehnološki fakultet, Varšava, Poljska.
} 
2018). Current trends in the development of the wood flooring industry include (Kozera, 2016): (1) optimisation of wood consumption (especially of high quality timber); (2) improvement in the quality of surface processing and joints; (3) development of easy, fast and permanent assembly technology of floor elements; (4) rich colouring and varied surface structure possibilities; (5) high durability and resistance of timber floor boards; (6) renovation possibilities.

In multi-layered floor materials, the support layer can be made of solid wood boards or peripherally cut veneers. In both cases, these raw materials are loaded with structural defects that decrease their strength parameters (Kretschmann, 2010). These defects can be eliminated or limited at the production stage. If veneers are used as load-bearing layers, the knots, especially loosed, are substantial defects. Their diameter can range from a few millimetres to several dozen. The negative influence of knots is manifested in the lowering of the tensile, bending and compression strength along the fibres and the modulus of elasticity (Phillips et al., 1981). This influence is caused, among other things, by the discontinuity of stresses due to the different orientation of wood fibres. In laboratory tests, knots can be treated the same as holes (Bano, 2009, Guindos and Guaita, 2013). In a multi-layered composite, negative influence of knots or holes on strength parameters is smaller than in solid wood. This is related to their presence only in one layer of material. These spots are a potential source for the propagation of cracks during loading. The filling of knotholes requires additional technological steps in the manufacturing process of composite timber floor boards. Some layered materials (e.g. floor boards), tend to be less exposed to typical bending loads. In this case, the hardness of the material plays a greater role. Numerous studies presented in the literature indicate that hardness of wood and wood-based materials is affected by its density and moisture content (Kollman and Cote, 1968, Holmberg, 2000, Han et al., 2007, Raymond, 2008, Franek et al., 2009). The Brinell method (Schwab, 1990) gives the most reliable results of measuring surface hardness. It allows to determine the real variability of surface hardness in particular anatomical directions and differences in hardness on the width of growth rings, which is confirmed by the studies of Hirata et al. (2001). However, Doyle and Walker (1984) draw attention to the inaccuracy of measurement in the Brinell method resulting from the relaxation of the steel ball impression. Hardness of the layered system is influenced both by the outer (surface) layer and its support (load-bearing layers). There is very few information in literature related to the effect of support layers on the hardness of the surface layer in composites. However, it is to be expected that possible free spaces located under the surface layer may affect the reduction in its hardness. This phenomenon will depend both: on the free spaces area (holes) and its position in relation to the surface layer.

The aim of this work was to determine the effect of knotholes located in the load-bearing layers of a five-layer wood composite on its strength parameters and the Brinell hardness of the surface layer.

\section{MATERIALS AND METHODS}

\section{MATERIJALI I METODE}

The research was carried out using five-layer timber floor boards with a nominal thickness of $15 \mathrm{~mm}$. The surface layer of the composite was sawn material - oak boards (Quercus robur L.). Four other layers (load-bearing layers) were made of circumferentially cut pine veneer (Pinus sylvestris L.). The individual layers were arranged to each other in a cross-shaped manner, providing an angle of 90 degrees between the fibres of the next layer. Oak boards had a nominal thickness of $3 \mathrm{~mm}$ and a moisture content of approx. 5 $\%$. Two variants of surface layer material were used during testing, different in terms of the anatomical cross-section of wood on the wide surface of planks: radial and tangential. Pine veneers had a nominal thickness of $3.2 \mathrm{~mm}$ and a moisture content of approx. $5 \%$. The thickness of the veneer resulted from the desire to limit the number of the load-bearing layers and thus the number of glue lines, while maintaining the final thickness of the entire floor panel. $3 \mathrm{~mm}$ thick veneer is used industrially for the production of LVL or plywood. Materials for all layers of floor boards were produced under industrial conditions with the preservation of standard technological conditions. An adhesive based on an industrial urea-formaldehyde resin (UF) was applied to consecutive layers. An industrial hardener was added to the resin in the amount of $5 \%$ by weight, enabling the composite pressing process to be carried out within $120 \mathrm{~s}$ at $120{ }^{\circ} \mathrm{C}$. The composites were produced with the use of laboratory hydraulic press at a unit pressure of $1.5 \mathrm{MPa}$.

The effect of knotholes of various diameters located in selected layers of the composite on its hardness was determined.

The following tests were carried out:

- hardness of the composite according to EN 1534:2011 Wooden floor - Determination of resistance to indentation (Brinell method) - Test method;

- density profile to determine density distribution in individual layers of the composite.

\subsection{Brinell hardness test}

\subsection{Tvrdoća prema Brinellu}

For the testing, samples with dimensions of 330 $\mathrm{mm} \times 150 \mathrm{~mm}$ (length $\times$ width) and a thickness resulting from the combination of a surface layer $(3.0 \mathrm{~mm})$ and four veneers (load-bearing layers - 4 × $3.2 \mathrm{~mm}$ ) were used (Figure 1). All layers were glued together with the direction of the grain in adjacent layers at right angles. The grain of the surface layer was parallel to the long edge of the panel. In the supporting layers (second and third, respectively), round gaps were prepared with diameters of: $10 \mathrm{~mm}, 20 \mathrm{~mm}$ and $50 \mathrm{~mm}$ (at one panel two gaps of each diameter) simulating knotholes. Location of gaps resulted from guidelines of the standard EN 1534:2011, which defines minimum distances between hardness measurement points. Control (reference) samples without round gaps were also prepared and tested. 

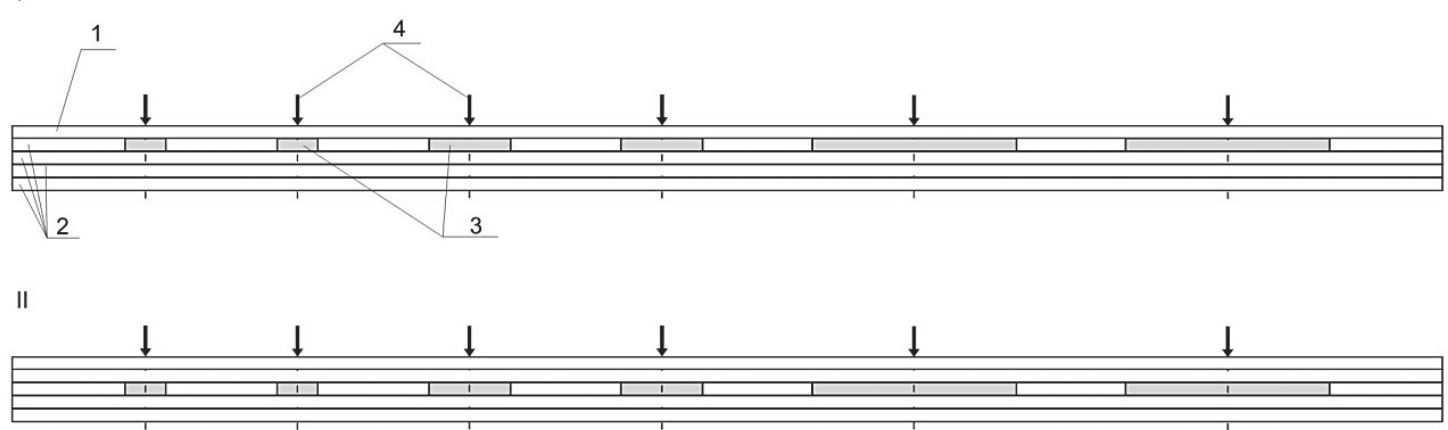

III
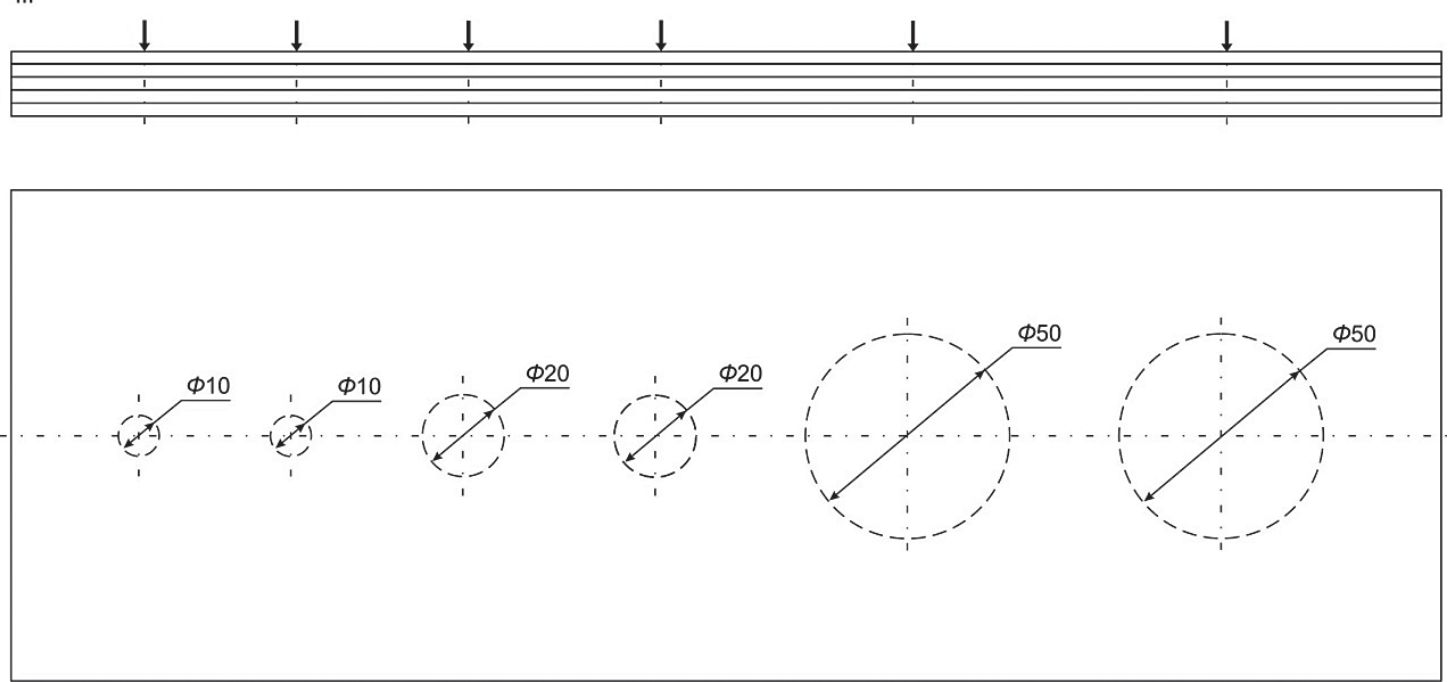

Figure 1 Samples for Brinell hardness test (I, II - variants of samples with round gaps simulating knotholes within the first and second sublayer, III - control variant, 1 - surface layer - oak wood, 2 - load-bearing layers - pine wood, 3 - round gaps, 4 - hardness measurement points on the surface layer)

Slika 1. Uzorci za mjerenje tvrdoće prema Brinellu (I, II - varijante uzoraka s rupama koje simuliraju rupe od kvrga u prvome i drugom podsloju, III - kontrolna varijanta, 1 - gazni sloj: drvo hrasta, 2 - središnji slojevi - drvo bora, 3 - rupe, 4 - mjesta za mjerenje tvrdoće na gaznom sloju)

Brinell hardness test was carried out with the use of CV-3000LDB equipment (CV Instruments, Bowers Group) in accordance with EN 1534:2011 standard. During testing a predetermined load of $1000 \mathrm{~N}$ was applied to a carbide ball of $10 \mathrm{~mm}$ diameter. It was held for a 20 second period and then removed. The resulting impression was measured with a microscope across two diameters (at right angles to each other) and these results were averaged. For each variant of samples and each grain layout of the surface layer (radial and tangential), 12 impressions were made.

\subsection{Density profile determination}

\subsection{Određivanje profila gustoće}

The study was conducted with the use of DAX GreCon Density Analyzer. Density distribution was determined on samples with dimensions: $50 \mathrm{~mm} \times 50$ $\mathrm{mm} \times 15 \mathrm{~mm}$. The distance between adjacent measurement points was $0.02 \mathrm{~mm}$, and the measurement speed was $0.05 \mathrm{~mm} / \mathrm{s}$.

\subsection{Numerical analysis \\ 2.3. Računska analiza}

To confirm possible dependencies, a numerical analysis was performed in SolidWorks Simulation environment. A model referring to the Brinell hardness test according to EN 1534: 2011 was created. The tested material was five layered composite timber floor board with oak surface layer ( $3 \mathrm{~mm}$ thick) and 4 other layers made of pine wood ( $4 \mathrm{~mm} \times 3.2 \mathrm{~mm}$ thick). The material properties used for FE-model are summarised in Table 1. The anisotropy of wood-based material was modelled using orthotropic properties. A static model with linear elastic material properties was used to study the stress distribution. The elastic constants adopted in the FEM analysis were taken from previous experimental work on small clear specimens of pine wood (Burawska, 2016). Material parameters for oak wood were selected on the basis of reports from literature (Kollmann and Cote, 1968; Krzysik, 1975).

The individual layers of the composite were arranged to each other in a cross-shaped manner and a "bonded" contact between them was established. Then, the composite was subjected to a load of $1000 \mathrm{~N}$, applied on the surface of a circle with a diameter of 10 $\mathrm{mm}$. Then, in load-bearing layers (second or third), round gaps with diameters of $10 \mathrm{~mm}, 20 \mathrm{~mm}, 30 \mathrm{~mm}$, $40 \mathrm{~mm}$ and $50 \mathrm{~mm}$ were made successively. The axes of round gaps were in the axis of the applied load. A solid standard mesh with a global size of approximately $1 \mathrm{~mm}$ was used, compacted in the vicinity of gaps 
Table 1 Material parameters of oak and pine wood - based on reports from literature (Kollmann and Cote, 1968; Krzysik, 1975)

Tablica 1. Svojstva drva hrasta i drva bora na temelju podataka iz literature (Kollmann and Cote, 1968.; Krzysik, 1975.)

\begin{tabular}{|l|c|c|c|c|c|c|c|c|c|}
\hline & $\begin{array}{c}\boldsymbol{E}_{\mathbf{1}} \\
\mathbf{N} / \mathbf{m m}^{\mathbf{2}}\end{array}$ & $\begin{array}{c}\boldsymbol{E}_{\mathbf{2}} \\
\mathbf{N} / \mathbf{m m}^{\mathbf{2}}\end{array}$ & $\begin{array}{c}\boldsymbol{E}_{\mathbf{3}} \\
\mathbf{N} / \mathbf{m m}^{\mathbf{2}}\end{array}$ & $\boldsymbol{\mu}_{\mathbf{1 2}}$ & $\boldsymbol{\mu}_{\mathbf{1 3}}$ & $\boldsymbol{\mu}_{\mathbf{2 3}}$ & $\begin{array}{c}\boldsymbol{G}_{\mathbf{1 2}} \\
\mathbf{N} / \mathbf{m m}^{\mathbf{2}}\end{array}$ & $\begin{array}{c}\boldsymbol{G}_{\mathbf{1 3}} \\
\mathbf{N} / \mathbf{m m}^{\mathbf{2}}\end{array}$ & $\begin{array}{c}\boldsymbol{G}_{\mathbf{2 3}} \\
\mathbf{N} / \mathbf{m m}^{\mathbf{2}}\end{array}$ \\
\hline Oak / Drvo hrasta & 13000 & 2190 & 990 & 0.5 & 0.43 & 0.62 & 1320 & 400 & 780 \\
\hline Pine / Drvo bora & 15000 & 1200 & 750 & 0.42 & 0.37 & 0.47 & 1070 & 107 & 1007 \\
\hline
\end{tabular}

and applied force. The total number of elements in each analysed computing case was about 3,900,000, and the number of nodes about 605,000 , respectively. The default failure criterion was related to the compressive strength across fibres of the five-layer composite overrun $\left(6 \mathrm{~N} / \mathrm{mm}^{2}\right)$.

\section{RESULTS AND DISCUSSION \\ 3. REZULTATI I RASPRAVA}

Hardness of composite timber floor boards is an important utility feature, strictly dependent on its density (Hirata et al., 2001), and in particular on the density of the surface layer. Tested layered materials were characterised by an average density of $618 \mathrm{~kg} / \mathrm{m}^{3}$; however, they differed in their thickness (Figure 2).

Surface layer of the composite made of oak boards (Quercus robur L.) had an average density of around $680 \mathrm{~kg} / \mathrm{m}^{3}$. The load-bearing layers made of pine veneer (Pinus sylvestris L.) were characterised by a density in the range of $411-778 \mathrm{~kg} / \mathrm{m}^{3}$, while welds reached a density above $1000 \mathrm{~kg} / \mathrm{m}^{3}$. During the gluing process, partial compression of pine wood occurred, evident in higher density of layers 1 and 5 (compared to layer 3). Additionally, adhesive penetrated the voids and irregularities in the surface area of individual veneers and hardened, which also influenced the material density in a weld zone (Lou et al., 2015).

The results of the Brinell hardness of the surface layer obtained during tests are presented in Table 2.

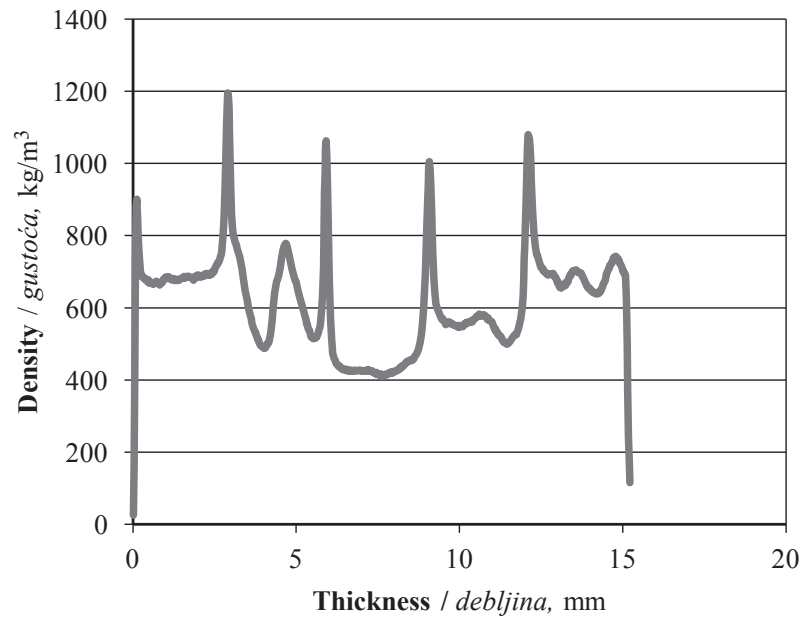

Figure 2 Exemplary density profile of layered composite - variant III (control)

Slika 2. Primjer profila gustoće višeslojne podne obloge varijanta III (kontrola)

Multi-layered composites without any round gaps in their structure were characterised by an average Brinell hardness of the surface layer of $45.9 \mathrm{~N} / \mathrm{mm}^{2}$.

Similar hardness results were reported regarding flooring materials made of cork oak (Quercus suber L.) - around $56 \mathrm{~N} / \mathrm{mm}^{2}$ and Portuguese oak (Quercus faginea L.) - around $50 \mathrm{~N} / \mathrm{mm}^{2}$ (Knapic et al., 2012). Tudor et al. (2018) stated that the hardness of parquets with a surface layer made of bark with a density of 700 $\mathrm{kg} / \mathrm{m}^{3}$ is around $39 \mathrm{~N} / \mathrm{mm}^{2}$. Knapic et al. (2012), in

Table 2 Results of Brinell hardness of tested variants of layered wood composites

Tablica 2. Rezultati tvrdoće prema Brinellu ispitivanih varijanti višeslojnih podnih obloga

\begin{tabular}{|c|c|c|c|c|c|c|c|c|c|}
\hline \multirow[t]{2}{*}{$\begin{array}{c}\text { Anatomical } \\
\text { cross-section of } \\
\text { surface layer } \\
\text { Anatomski } \\
\text { presjek gaznog } \\
\text { sloja } \\
\end{array}$} & \multirow{2}{*}{\multicolumn{2}{|c|}{$\begin{array}{c}\text { Brinell hardness } \\
\text { Tvrdoća prema } \\
\text { Brinellu }\end{array}$}} & \multirow[t]{2}{*}{$\begin{array}{c}\text { Control } \\
\text { no round gaps } \\
\text { (variant III) } \\
\text { Kontrola bez } \\
\text { rupa (varijanta } \\
\text { III) } \\
\end{array}$} & \multicolumn{3}{|c|}{$\begin{array}{c}\text { Diameter of round gap } \\
\text { located in layer } \mathbf{2} \\
\text { (variant } \mathbf{I}), \mathbf{m m} \\
\text { Promjer rupa u drugom sloju } \\
\text { (varijanta I), mm }\end{array}$} & \multicolumn{3}{|c|}{$\begin{array}{c}\text { Diameter of round gap } \\
\text { located in layer } \mathbf{3} \\
\text { (variant } \text { II), mm } \\
\text { Promjer rupa } u \text { trećem sloju } \\
\text { (varijanta II), mm }\end{array}$} \\
\hline & & & & 10 & 20 & 50 & 10 & 20 & 50 \\
\hline \multirow{5}{*}{$\begin{array}{l}\text { Radial } \\
\text { radijalni presjek }\end{array}$} & average & \multirow{4}{*}{$\mathrm{N} / \mathrm{mm}^{2}$} & $45.9^{\mathrm{b} . \mathrm{A}}$ & $22.2^{\mathrm{a}}$ & - & - & $39.5^{\mathrm{b} . \mathrm{A}}$ & $43.3^{\mathrm{A}}$ & $39.3^{\mathrm{A}}$ \\
\hline & $\max$ & & 62.4 & 33.8 & - & - & 49.9 & 56.3 & 50.8 \\
\hline & $\min$ & & 37.9 & 14.8 & - & - & 32.3 & 31.0 & 29.5 \\
\hline & stand. dev. & & 8.8 & 6.2 & - & - & 5.5 & 8.3 & 7.7 \\
\hline & $\mathrm{COV}$ & $\%$ & 19.1 & 28 & - & - & 13.9 & 19.1 & 19.7 \\
\hline \multirow{5}{*}{$\begin{array}{l}\text { Tangential } \\
\text { tangentni presjek }\end{array}$} & average & \multirow{4}{*}{$\mathrm{N} / \mathrm{mm}^{2}$} & $44.5^{\mathrm{b} . \mathrm{A}}$ & $21.6^{\mathrm{a}}$ & - & - & $36.0^{\mathrm{b} . \mathrm{A}}$ & $38.6^{\mathrm{A}}$ & $45.7^{\mathrm{A}}$ \\
\hline & $\max$ & & 63.4 & 28.8 & - & - & 59.5 & 56.6 & 61.1 \\
\hline & $\min$ & & 34.2 & 14.0 & - & - & 25.5 & 26.1 & 36.5 \\
\hline & stand. dev. & & 9.5 & 6.2 & - & - & 8.7 & 9.2 & 9.5 \\
\hline & $\mathrm{COV}$ & $\%$ & 21.3 & 29.0 & - & - & 24.2 & 23.9 & 20.7 \\
\hline
\end{tabular}

COV - coefficient of variation / koeficijent varijacije

$* \mathrm{a}, \mathrm{b}$ - homogeneous groups for the analysis of the impact of round gaps (diameter $10 \mathrm{~mm}$ ) location / *a, b - homogene grupe za analizu utjecaja položaja rupa (promjer $10 \mathrm{~mm}$ )

**A - homogeneous groups for the analysis of the impact of round gaps (diameter $10 \mathrm{~mm}, 20 \mathrm{~mm}, 50 \mathrm{~mm}$ ) located in layer $3 / * * \mathrm{~A}-$ homogene grupe za analizu utjecaja rupa (promjer 10, 20 i $50 \mathrm{~mm}$ ) smještenih u trećem sloju 


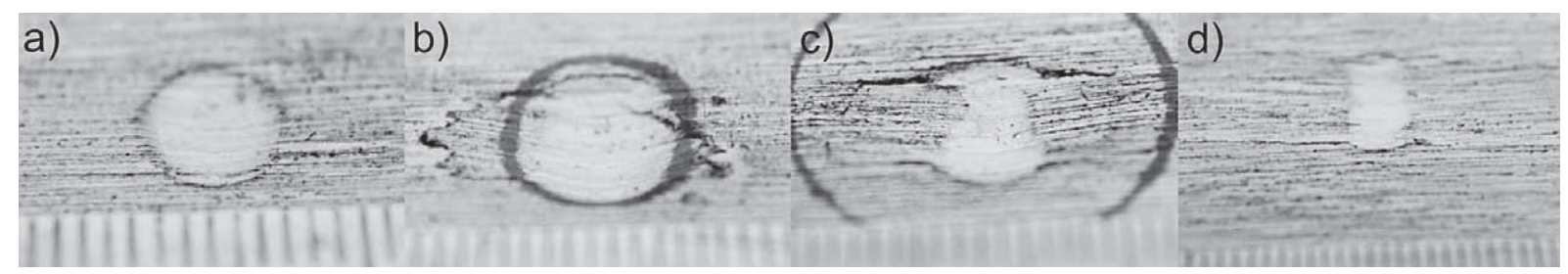

Figure 3 Sample indentations in the surface of layered composite samples with round gaps simulating knotholes located in layer 2 (variant I) after hardness testing: a) control sample, b) sample with a $110 \mathrm{~mm}$ round gap, c) sample with a $\mathrm{f} 20 \mathrm{~mm}$ round gap, d) sample with a $\phi 50 \mathrm{~mm}$ round gap

Slika 3. Udubljenje na površini uzoraka višeslojne podne obloge s rupama u drugom sloju koje simuliraju rupe od kvrga (varijanta I) nakon ispitivanja tvrdoće: a) kontrolni uzorak, b) uzorak s rupom promjera $10 \mathrm{~mm}$, c) uzorak s rupom promjera $20 \mathrm{~mm}$, d) uzorak s rupom promjera $50 \mathrm{~mm}$

turn, stated that softwood materials usually have much lower Brinell hardness values (in the range of 13-25 N/ $\mathrm{mm}^{2}$ ). With respect to conducted tests, it can be generally stated that unfilled round gaps located in the composite load-bearing layers (second or third, respectively), depending on their location and diameter, significantly affect its hardness.

The arrangement of round gaps simulating knots with diameters of 20 and $50 \mathrm{~mm}$ in layer 2 caused deflection of the surface layer as well as cracks (Figure 3 ). That is why the obtained results could be inconclusive. In the case of $10 \mathrm{~mm}$ diameter round gaps, a statistically significant decrease in the hardness of the composite was noted, reaching over $50 \%$ of the initial hardness (without a gap in the supporting layer).

A variance analysis showed a significant effect of the layer containing round gaps (Table 3 ). Round gaps located in layer 3 of the composite (variant II) did not significantly change its hardness with respect to control (Table 4). It is worth noting that virtually in all tested variants (both with unfilled gaps in layer 3 and control), similar values of variability coefficients were recorded.

Despite the lack of a statistically significant decrease in Brinell hardness values for all tested cases of variant II (in relation to control), attention should be paid to the high local elasticity of wood composites, especially when round gaps of $50 \mathrm{~mm}$ diameter were placed in layer 3. In this case, during hardness test, a visible deflection of the composite surface layer occurred as a result of lack of the support (free space). However, noticeable deflection of material did not cause visible damage (cracks) on the surface of the oak planks, but it could lead to the formation of hard-to-detect microcracks, which ultimately weakened the examined cross-section. The deflection of surface layer during the test could also have influenced the superficial gain in hardness value, especially in case of tangential anatomical cross-section of surface layer. As a result of the materials deflection, ball indicator could give impression of a smaller diameter on its oak surface layer. All obtained hardness vales exceeded $10 \mathrm{~N} / \mathrm{mm}^{2}$, which is the mini-

Table 3 ANOVA table - place of empty spot and cross-section of top layer

Tablica 3. ANOVA tablica - položaj rupa i presjek gaznog sloja

\begin{tabular}{|l|c|c|c|c|c|c|}
\hline \multicolumn{1}{|c|}{$\begin{array}{c}\text { Source of variance } \\
\text { Izvor odstupanja }\end{array}$} & SS & Df & MS & $\boldsymbol{F}$ & $\boldsymbol{p}$ & $\boldsymbol{P ( \% )}$ \\
\hline $\begin{array}{l}\text { Anatomical cross-section of surface layer (CS) } \\
\text { anatomski presjek gaznog sloja (CS) }\end{array}$ & 44.01 & 1 & 44.01 & 0.75 & 0.389 & 0.62 \\
\hline Layer with round gap (LRG)/ sloj s rupama (LRG) & 4157.02 & 2 & 2078.51 & 35.66 & 0.000 & 59.21 \\
\hline CS x LRG & 21.98 & 2 & 10.99 & 0.19 & 0.829 & 0.31 \\
\hline Error / pogreška & 2797.79 & 48 & 58.29 & & & 39.85 \\
\hline
\end{tabular}

$S S$ - sum of squared deviations from the mean value, $D f$ - degrees of freedom, $M S$ - mean square $(M S=S S / D f)$,

$F$ - test value, $p$ - probability of error, $X$ - percentage effect of factors on the analysed parameter / SS - zbroj kvadratnih odstupanja od srednje vrijednosti, $D f$-stupnjevi slobode, $M S$ - srednji kvadrat $(M S=S S / D f), F-v r i j e d n o s t ~ i s p i t i v a n j a, p-v j e r o j a t n o s t ~ p o g r e s ̌ k e, ~ X-p o s t o t n i$ utjecaj čimbenika na analizirani parametar

Table 4 ANOVA table - unfilled round gap in layer 3 of the composite with respect to control

Tablica 4. ANOVA tablica - neispunjena rupa u trećem sloju višeslojne podne obloge s obzirom na kontrolni uzorak

\begin{tabular}{|l|c|c|c|c|c|c|}
\hline \multicolumn{1}{|c|}{$\begin{array}{c}\text { Source of variance } \\
\text { Izvor odstupanja }\end{array}$} & SS & Df & MS & $\boldsymbol{F}$ & $\boldsymbol{p}$ & $\boldsymbol{P ( \% )}$ \\
\hline $\begin{array}{l}\text { Anatomical cross-section of surface layer (CS) } \\
\text { anatomski presjek gaznog sloja (CS) }\end{array}$ & 12.30 & 1 & 12.30 & 0.18 & 0.676 & 0.21 \\
\hline Layer with round gap (LRG) / sloj s rupama (LRG) & 559.00 & 3 & 186.30 & 2.67 & 0.054 & 9.69 \\
\hline CS x LRG & 305.30 & 3 & 101.80 & 1.46 & 0.234 & 5.29 \\
\hline Error / pogreška & 4892.10 & 70 & 69.90 & & & 84.80 \\
\hline
\end{tabular}

$S S$ - sum of squared deviations from the mean value, $D f$ - degrees of freedom, $M S$ - mean square $(M S=S S / D f)$,

$F$ - test value, $p$ - probability of error, $X$ - percentage effect of factors on the analysed parameter / SS - zbroj kvadratnih odstupanja od srednje vrijednosti, $D f$ - stupnjevi slobode, $M S$ - srednji kvadrat $(M S=S S / D f), F$-vrijednost ispitivanja, $p$ - vjerojatnost pogreške, $X$ - postotni utjecaj čimbenika na analizirani parametar 
Table 5 Hardness requirements for different flooring applications (EN 14354:2017)

Tablica 5. Zahtijevana tvrdoća drvenih podnih obloga s obzirom na mjesto uporabe (EN 14354:2017)

\begin{tabular}{|l|c|c|}
\hline \multicolumn{2}{|c|}{ Level of use / Stupanj opterećenja } & Hardness / Tvrdoća, N/mm ${ }^{2}$ \\
\hline \multirow{3}{*}{ Domestic / Kućna uporaba } & Moderate / umjeren & $\geq 10$ \\
\cline { 2 - 3 } & General / normalan & $\geq 20$ \\
\cline { 2 - 3 } & Heavy / velik & $\geq 30$ \\
\hline \multirow{3}{*}{ Commercial / Javna uporaba } & Moderate / umjeren & $\geq 40$ \\
\cline { 2 - 3 } & General / normalan & $\geq 40$ \\
\cline { 2 - 3 } & Heavy / velik & \\
\hline
\end{tabular}

mum acceptable value for wooden floors in several European standards. The EN 14354:2017 standard specifies hardness reference values for floor materials depending on various end uses (Table 5).

Based on presented data (Table 2 and 5), it could be noticed that all tested multi-layered composites can be used in all domestic applications. In case when gaps are located in layer 3, tested composites can also be used in commercial applications with moderate traffic.

Tests showed that there is no influence of an anatomical cross-section of surface layer (radial, tangential) on Brinell hardness, which was also confirmed by statistical variance analysis (Tables 3 and 4). This is also consistent with the literature (e.g. Kretschmann, 2010).

Table 6 presents the results of the numerical analysis carried out for individual variants of wood composites. Minimum and maximum values of stresses were read in the vicinity of the applied force and round gap simulating the knot. Figures 4, 5 and 6 show maps of normal stresses occurred in case of $1000 \mathrm{~N}$ loading $\left(\sigma_{\mathrm{x}}, \sigma_{\mathrm{y}}\right.$ and $\left.\sigma_{\mathrm{z}}\right)$.

The control variant (without gaps) was characterised by the smallest values of normal stresses in all di-

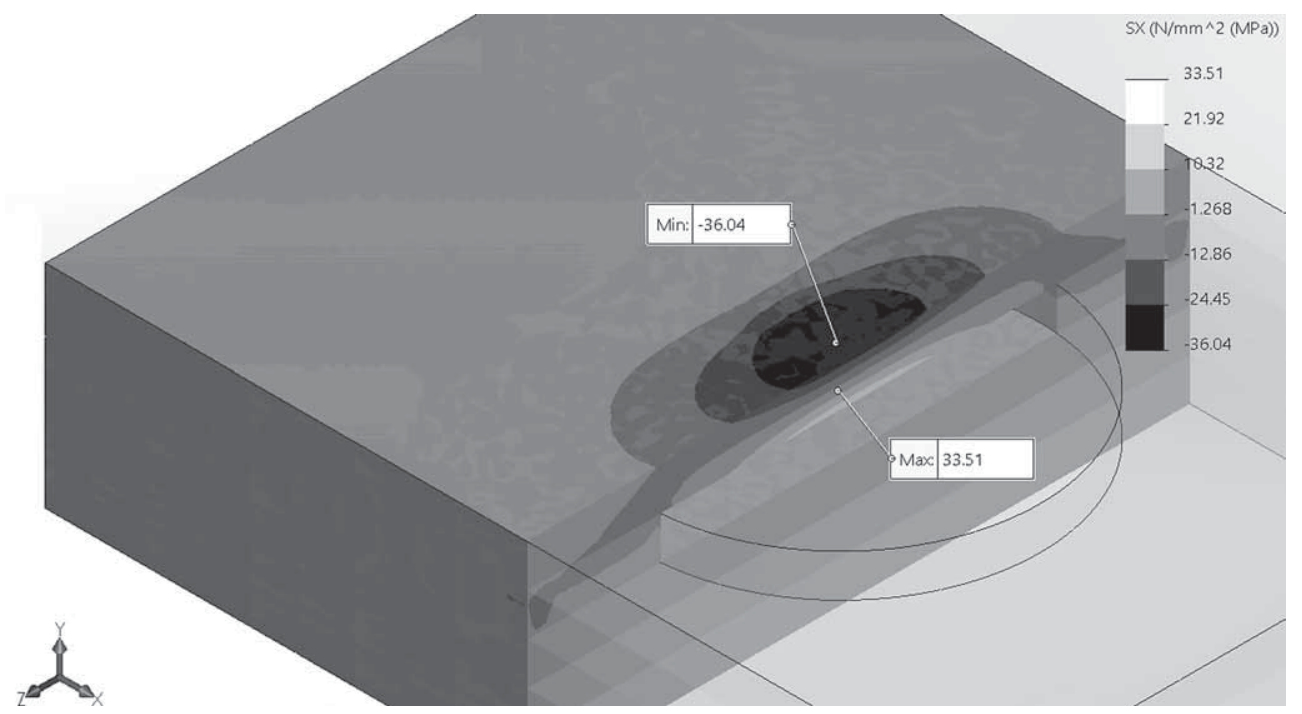

Figure 4 Map of normal stress $\sigma_{\mathrm{x}}(1000 \mathrm{~N}$ load, round gap diameter $30 \mathrm{~mm})$

Slika 4. Prikaz normalnog naprezanja $\sigma_{x}$ (opterećenje $1000 \mathrm{~N}$, rupa promjera $30 \mathrm{~mm}$ )

Table 6 Results of numerical analysis of wood composite variants

Tablica 6. Rezultati računske analize varijanti višeslojnih podnih obloga

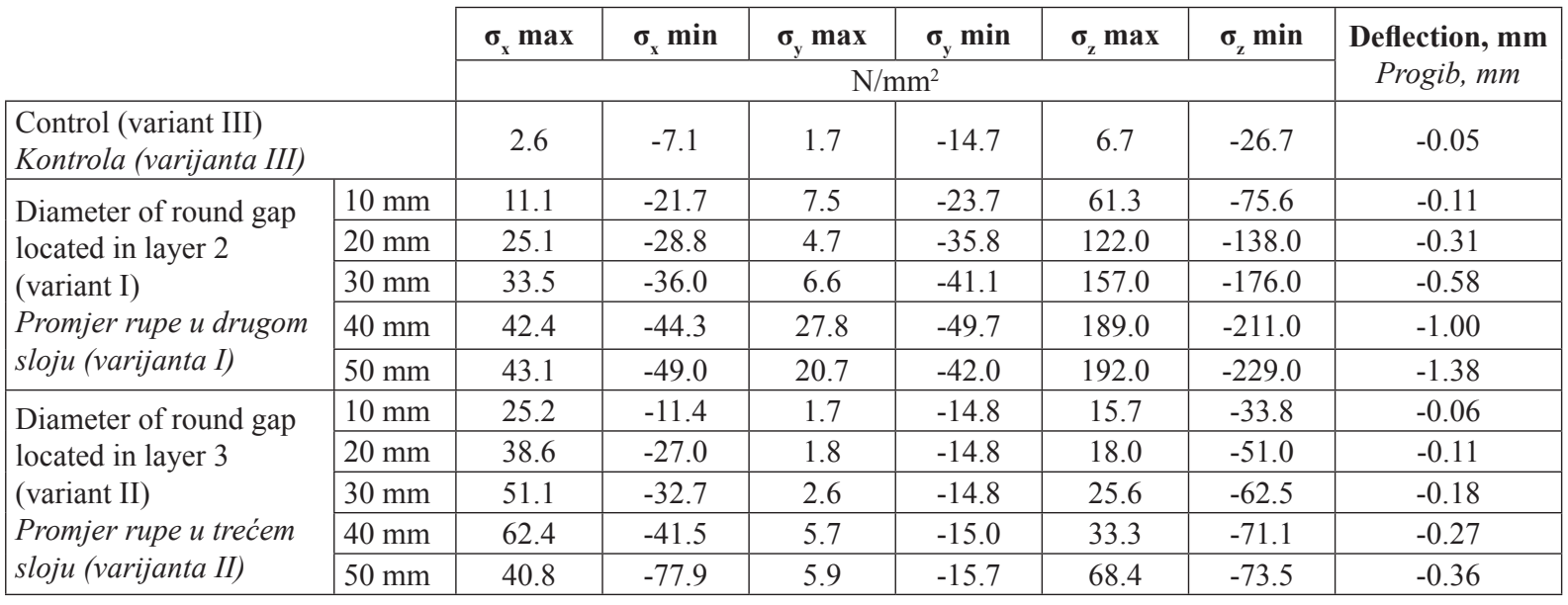




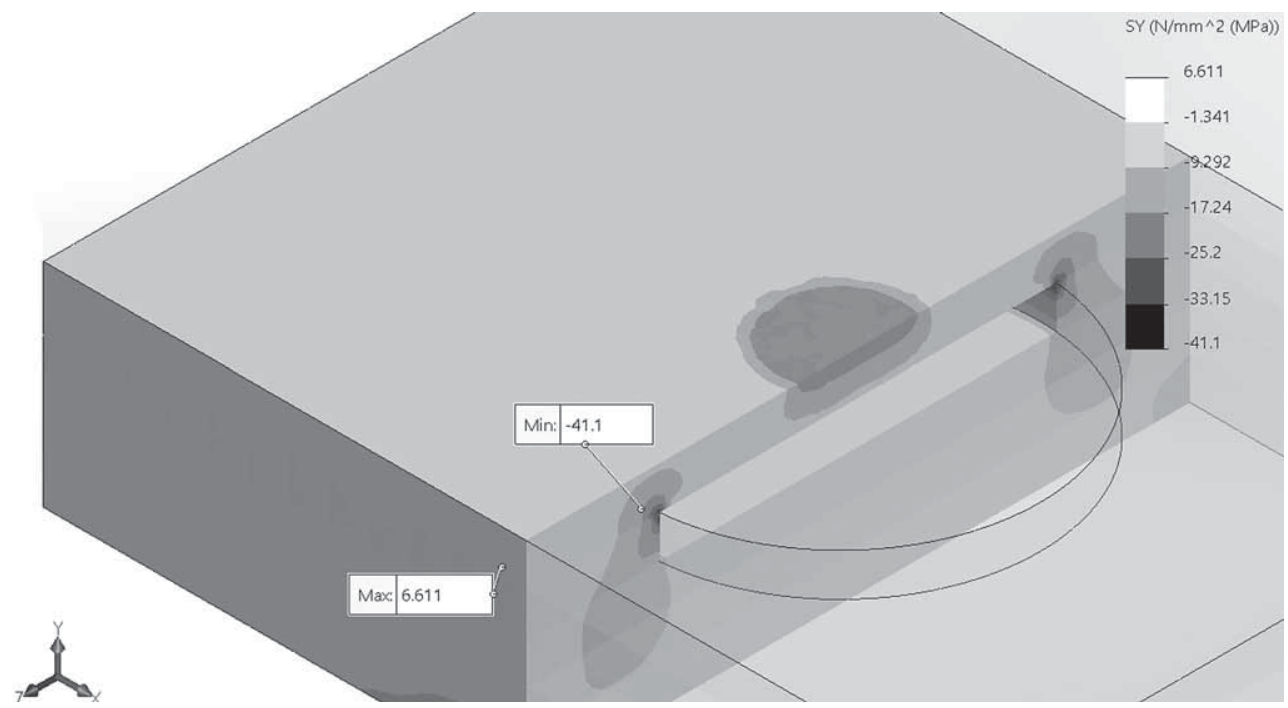

Figure 5 Map of normal stress $\sigma_{\mathrm{y}}(1000 \mathrm{~N}$ load, round gap diameter $30 \mathrm{~mm})$

Slika 5. Prikaz normalnog naprezanja $\sigma_{\mathrm{y}}$ (opterećenje $1000 \mathrm{~N}$, rupa promjera $30 \mathrm{~mm}$ )

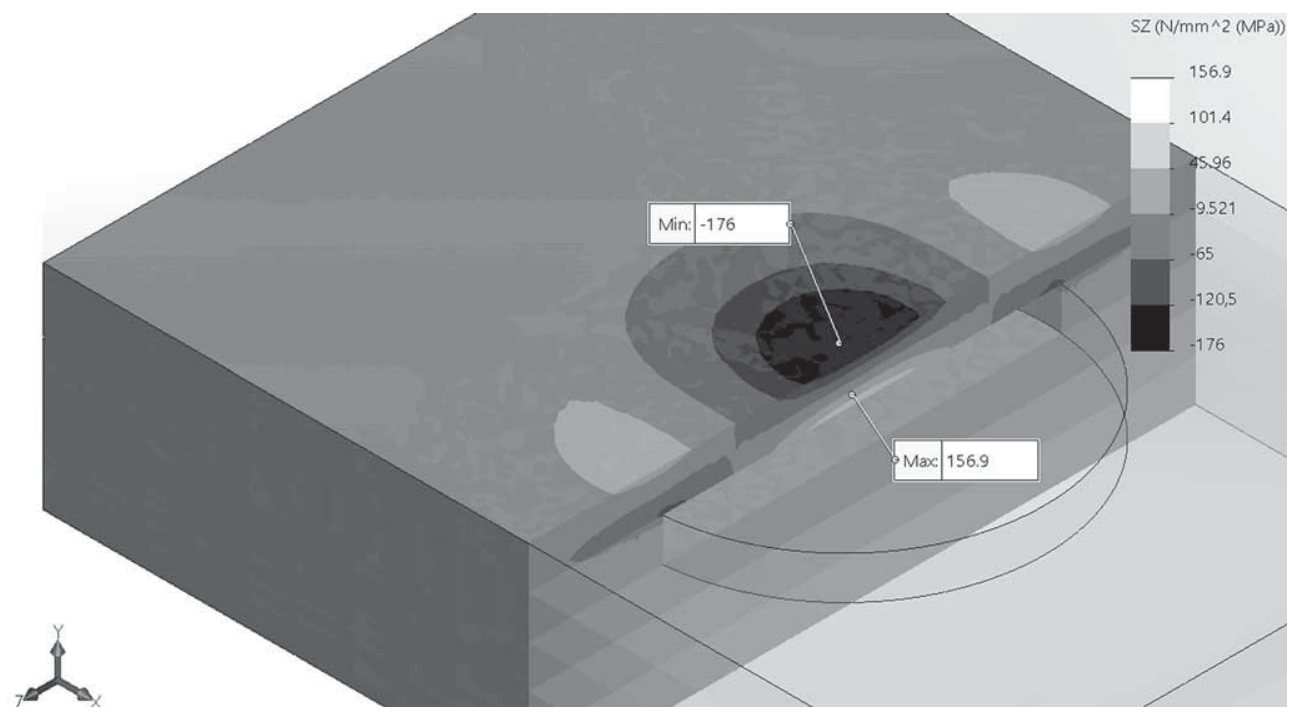

Figure 6 Map of normal stress $\sigma_{\mathrm{z}}(1000 \mathrm{~N}$ load, round gap diameter $30 \mathrm{~mm})$

Slika 6. Prikaz normalnog naprezanja $\sigma_{z}$ (opterećenje $1000 \mathrm{~N}$, rupa promjera $30 \mathrm{~mm}$ )

rections $\left(\sigma_{\mathrm{x}}, \sigma_{\mathrm{y}}\right.$ and $\left.\sigma_{\mathrm{z}}\right)$ in relation to composites with material defects in their layout. With the increase in the diameter of round gaps simulating defect (both in layer 2 and 3), the values of deflections increase, as well as individual stress components in most cases. Round gaps located in layer 3 of the composite (variant II) affect the values of stresses in respective layers to a very limited extent. It should be noted that there is no impact of gaps of any diameter located in layer 3 on stress values $\sigma_{\mathrm{y}}$ (in the load plane). In the case of gaps located in layer 2 , the impact of the hole, even with a diameter of $10 \mathrm{~mm}$, is manifested by a significant increase in all stress components as well as deflection, resulting from the lack of direct material support within the defect.

\section{CONCLUSIONS}

\section{ZAKLJUČAK}

It is possible to use veneers with defects (unfilled gaps) with a diameter of up to $20 \mathrm{~mm}$ as an internal layer (3rd or subsequent, counting from the surface layer) of multi-layered composite.

The Brinell hardness, determined on the longitudinal sections of oak wood as surface layer of layered composite, is around $45.2 \mathrm{~N} / \mathrm{mm}^{2}$. When using veneer with defect (round unfilled gap of diameter up to 20 $\mathrm{mm}$ ) as a layer 3 or subsequent, hardness values of surface layer are in the range of $36.0-43.3 \mathrm{~N} / \mathrm{mm}^{2}$.

The anatomical cross-section of the surface layer (radial, tangential) does not affect the hardness values of multi-layered composite.

\section{Acknowledgements - Zahvala}

The authors are grateful for the support of the National Centre for Research and Development, Poland, under "Environment, agriculture and forestry" BIOSTRATEG strategic R\&D programme, agreement No. BIOSTRATEG2/298950/1/NCBR/2016. 


\section{REFERENCES}

\section{LITERATURA}

1. Bano, V., 2009: Numerical analysis of wood strength loss due to presence of knots, $\mathrm{PhD}$ thesis. Polytechnic University of Madrid. Madrid.

2. Burawska, I., 2015: Local reinforcement of pine structural timber (Pinus sylvestris L.), PhD thesis. Warsaw University of Life Sciences - SGGW.

3. Doyle, J.; Walker, J. C. F., 1984: Indentation hardness of wood. Wood Fibre Science, 17 (3): 369-376.

4. Franek, F.; Badisch, E.; Kirchgaßner, M., 2009: Advanced methods for characterisation of abrasion/erosion resistance of wear protection materials. FME Transactions, 2 (37): 61-70.

5. Guindos, P.; Guaita, M., 2013: A three-dimensional wood material model to simulate the behavior of wood with any type of knot at the macro-scale. Wood Science and Technology, 47: 585-599. http://dx.doi.org/10.1007/s00226-012-0517-4.

6. Han, G.; Wu, Q.; Lu, J. Z., 2007: The influence of fines content and panel density on properties of mixed hardwood oriented strand boards. Wood Fiber Science, 39 (1): 2-15.

7. Hirata, S.; Ohta, M.; Honma, Y., 2001: Hardness distribution on wood surface. Journal of Wood Science, 47(1): 1-7. http://dx.doi.org/10.1007/BF00776637.

8. Holmberg, H., 2000: Influence of grain angle on Brinell hardness of Scots pine (Pinus sylvestris L.), Holtz als Roh- und Werkstoff, 58 (1/2): 91-95. http://dx.doi. org/10.1007/s001070050392.

9. Knapic, S.; Machado, J. S.; Pereira, H., 2012: Properties of cork oak wood related to solid wood flooring performance. Construction and Building Materials, 30: 569573.

http://dx.doi.org/10.1016/j.conbuildmat.2011.11.014.

10. Kollmann, F. F. P.; Cote, W. A., 1968: Principles of wood science and technology. Solid Wood. Springer-Verlag Berlin Heidelberg, New York, pp. 592.

11. Kozera, D., 2016: Innovation in the wood flooring production. In: Proceedings of The National scientific and technical conference: Innovation in the Polish wood sector - strengths and weaknesses, Warsaw, May 12, 2016, p.p. 37-40 (in Polish).

12. Kretschmann, D. E., 2010: Mechanical properties of wood. In: Wood handbook - Wood as an engineering material. Centennial edition. General technical report FPL; GTR-190, Ross, R. J. (ed.). Madison, Wisconsin: U.S. Department of Agriculture, Forest Service, Forest Products Laboratory, pp. 100-145.
13. Krzysik, F., 1975: Wood science. Państwowe Wydawnictwo Naukowe. Warsaw, p.p. 663 (in Polish).

14. Luo, J.; Luo, J.; Gao, Q.; Li, J., 2015: Effects of heat treatment on wet shear strength of plywood bonded with soybean meal-based adhesive. Industrial Crops and Products, 63: 281-286. http://dx.doi.org/10.1016/j.indcrop.2014.09.054.

15. Phillips, G. E.; Bodig, J.; Goodman, J. R., 1981: Flow grain analogy. Wood Science, 14: 55-64.

16. Raymond, C., 2008: Influence of wood density and fibre length on properties of medium density fibreboard manufactured from Pinus radiata. Appita Journal: Journal of the Technical Association of the Australian and New Zealand Pulp and Paper Industry, 60 (3): 204-208.

17. Schwab, E., 1990: Die Härte von Laubhölzern für die Parkettherstellung [The hardness of hardwoods for parquet production]. Holz als Roh- und Werkstoff, 48 (2): 47-51 (in German). https://doi.org/10.1007/BF02610703.

18. Tudor, E. M.; Barbu, M. C.; Petutschnigg, A.; Réh, R., 2018: Added-value for wood bark as a coating layer for flooring tiles. Journal of Cleaner Production, 170: 13541360. http://dx.doi.org/10.1016/j.jclepro.2017.09.156.

19. ${ }^{* * *}$ EN 14354, 2017: Wood-based panels - wood veneer floor coverings. CEN, European Committee for Standardization, Brussels, Belgium, p.p. 51.

20. ***EN 1534, 2010: Wood flooring. Determination of resistance to indentation. Test method. CEN, European Committee for Standardization, Brussels, Belgium, pp. 9.

21. ***FEP, 2018a: The Parquet Industry. Facing the future with optimism (online). http://www.parquet.net/ files/2017__FEP__Market__June_PR.pdf (Accessed May 17,2018$)$.

22. ***FEP, 2018b: The Parquet Industry. Parquet (online). http://www.parquet.net/files/2017___FEP___Parquet.pdf (Accessed May 17, 2018).

23. ***KEN'S YARD, 2018: Why is engineered wood flooring better than solid wood? (online). http://www.kensyard.co.uk/product-guides/why-is-engineered-flooringbetter-than-solid/ (Accessed May 28, 2018).

\section{Corresponding address:}

\section{PIOTR BORYSIUK}

Warsaw University of Life Sciences - SGGW

Faculty of Wood Technology

Nowoursynowska Str. 159, 02-776 Warsaw, POLAND e-mail: piotr_borysiuk@sggw.pl 